\section{Barrier Effect of the Shrub Elaeagnus commutata on Grazing Cattle and Forage Production in Central Alberta ${ }^{1}$}

\author{
ARTHUR W. BAILEY \\ Department of Plant Science, University of Alberta, \\ Edmonton, Alberta, Canada.
}

\section{Highlight}

Excellent condition range occurred under silverberry shrubs while fair to good condition range occurred between shrubs. The herbaccous layer dominants, rough fescue and western porcupine grass, produced nearly twice as much under shrubs. Forb increasers had a lower frequency and produced less herbage under shrubs. Silverberry is an increaser but the barrier effect it has on grazing cattle permitted a small patch of grassland directly beneath each shrub to return to near-climax condition.

Silverberry (Elaeagnus commutata ${ }^{2}$ ) is an important shrub in the central Alberta parkland. Many stems are interconnected to form a clone. The roots of the shrub bear nodules which are capable of fixing nitrogen (Moore, 1964). Studies of the fescue grasslands in Alberta (Moss and Campbell, 1947) and Saskatchewan (Coupland and Brayshaw, 1953) revealed that the shrub occurred only occasionally about 20 years ago. Silverberry is now widely distributed in these grasslands. The cause of increased shrub cover has not been investigated. It is probably related to overgrazing and cycles of high annual precipitation.

Shrubs and trees often reduce the potential yield of understory forage species (Blaisdell, 1949; Ivan, 1960; Johnston and Smoliak, 1968; Little, 1961; Robertson, 1947; Scott, 1967; and Thomas et al., 1968). The detrimental effects of woody plants on economically important herbaceous species are widely known but the beneficial effects of a few shrubs on palatable forage species is often overlooked. In a crested wheatgrass stand having both rubber rabbitbrush and big sagebrush, Frischknecht (1963) found that when grazed, more forage was produced directly under rubber rabbitbrush than in adjacent openings. Big sagebrush, in contrast, lowered forage yields. The barrier effect of a plant

\footnotetext{
${ }^{1}$ Received June 6, 1969; accepted for publication August 9, 1969. Parts of the paper were presented at the Annual Convention, American Society of Range Management February 11-13, 1969 under the title "Beneficial Effects of Silverberry (Elaeagnus commutata) on range condition in central Alberta." Appreciation is extended to Dr. W. G. Corns, Dr. R. T. Berg and Mr. J. A. Campbell for critical review of the manuscript.

${ }^{2}$ Common and scientific names follow Moss (1959).
}

on a grazing animal is not limited to shrubs and domestic livestock. Daubenmire (1968) showed in a photograph (p. 59) that grazing jackrabbits had destroyed all phlox growing between clumps of bluebunch wheatgrass. The only surviving plants were in the protection of clumps of wheatgrass.

Corns and Schraa (1965) observed that silverberry interfered with utilization of forage by cattle. In an experiment that excluded grazing, they found no significant increase in herbage yield when silverberry was killed with herbicides. In contrast, Mclver (1963) obtained increased forage yield when silverberry, aspen poplar and snowberry (Symphoricarpos sp.) werc controlled. Since the yield data were lumped, however, no conclusions can be made about the separate effect of each species on forage yield.

This paper pursues further some of the observations of Corns and Schraa (1965). The objective was to investigate the effect of silverberry on forage production and utilization by grazing cattle.

\section{Study Area and Methods}

The study was conducted on the University of Alberta Ranch, 95 miles southeast of Edmonton, Albcrta. The major types of vegetation are the fescue grasslands and aspen poplar (Populus tremuloides) groves. The fescue grasslands occurred on uplands underlain by soils of the Dark Brown or Thin-black soil zones while the aspen groves usually occupied depressions having deeper soils of the Black or Dark Grey Wooded soil zones.

in the study area, the shrub layer was dominated by 12 to 17 year old stands of silverberry. The shrub had about $40 \%$ canopy cover and 1000 stems per acre (Fig. 1). The herbaceous layer was dominated by rough fescue. The orthic chernozem soils have developed on glacial outwash material. Soils were very stony loams. The average annual precipitation was 15 inches with 10 inches occurring in the growing season (Can. Dept. Transport. Meteorol. Div., 1966, 1967).

The study area was used as a calving range. Grazing was from about April 1 to June 15 each year.

Five 10 by $20 \mathrm{ft}$ cattle exclosures were randomly located and erected in the spring of 1967 prior to grass growth. Line transects 3 by $16 \mathrm{ft}$ were randomly located within the exclosures; the transects extended an equal distance outside. Ten shrubs within the transects, 5 inside and 5 outside the exclosure, were randomly selected for sampling. A 10 inch diameter circular plot was located directly under the shrub. Another plot of the same size was randomly located in an adjacent opening between shrubs. Twenty-five paired plots were sampled for herbage yield inside the exclosure and another 25 outside. Eight pairs were lost in transport resulting in the comparisons being made on 17 pairs. The 17 pairs of 10 inch plots inside the exclosures permitted an estimate of herbage production under shrubs and between them. The difference in yield inside versus outside the exclosures permitted an estimate of utilization. Once the cattle were removed in mid-June, all herbage was clipped, bagged and frozen. At a later date, dead herbage was separated into dead grass and dead forbs; the green 


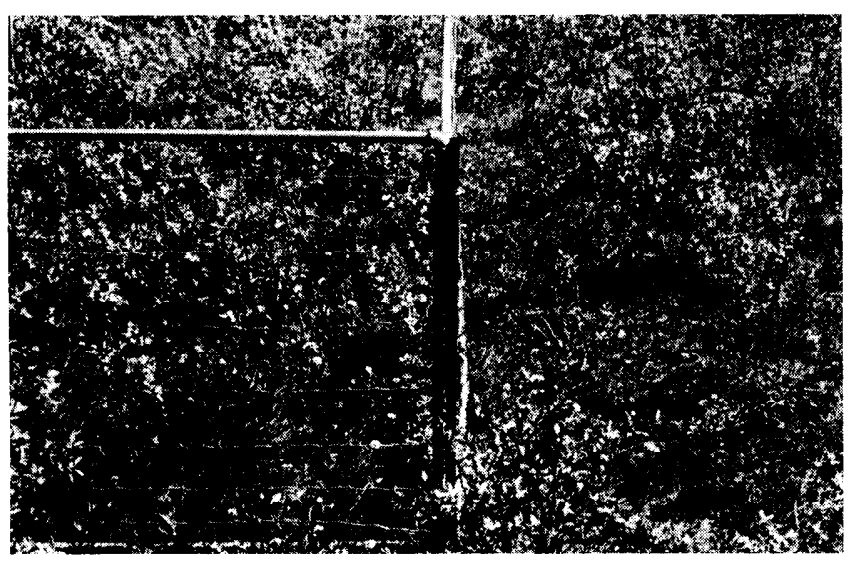

FIG. 1. Silverberry-rough fescue range at end of grazing period, ungrazed-left, grazed-right.

herbage was hand-sorted to species, oven dried and weighed. Rough fescue and western porcupine grass were lumped together because their vegetative parts were indistinguishable after freezing. Western porcupine grass constituted from $5-25 \%$ of the combined weight.

\section{Results and Discussion}

The openings between shrubs had a richer flora than under shrubs (Table 1). Many of the forb increasers or invaders had a considerably higher frequency between shrubs and four species with frequency values ranging from $9-27 \%$ only occurred between the shrubs. These observations agree with Moss and Campbell (1947) who noted that under pristine conditions, rough fescue grew almost to the exclusion of other higher plants but under grazing or mowing, secondary grasses, sedges and forbs increased in importance.

Production figures in Table 2 substantiate the frequency data. There was significantly more herbage under shrubs than between them. Of the $1092 \mathrm{lb} /$ acre more under shrubs, only one-fifth, $232 \mathrm{lb} / \mathrm{acre}$, was green growth; the rest was dead

Table 1. Frequency ( $\%$ of 34 observations) of occurrence of selected species.

\begin{tabular}{lcc}
\hline \hline \multicolumn{1}{c}{ Species } & $\begin{array}{c}\text { Under } \\
\text { shrubs }\end{array}$ & $\begin{array}{c}\text { Between } \\
\text { shrubs }\end{array}$ \\
\hline Golden aster (Chrysopsis villosa) & & 9 \\
Prickly rose (Rosa acicularis) & & 9 \\
Pussy-toes (Antennaria sp.) & & 12 \\
Milk vetch (Astragalus striatus) & 27 \\
Western willow aster (Aster hesperius) & 18 & 29 \\
Mouse-ear chickweed (Cerastium arvense) & 15 & 38 \\
Wild strawberry (Fragaria virginiana) & 32 & 47 \\
Dandelion (Taraxacum officinale) & 59 & 85 \\
Prairie sage (Artemisia ludoviciana) & 85 & 94 \\
Blunt sedge (Carex obtusata) & 94 & 100 \\
Rough fescue (Festuca scabrella) & & \\
and Western porcupine grass & & \\
(Stipa spartea var. curtiseta) & 100 & 100 \\
\hline
\end{tabular}

Table 2. Production (lb/acre) under shrubs versus in openings between shrubs.

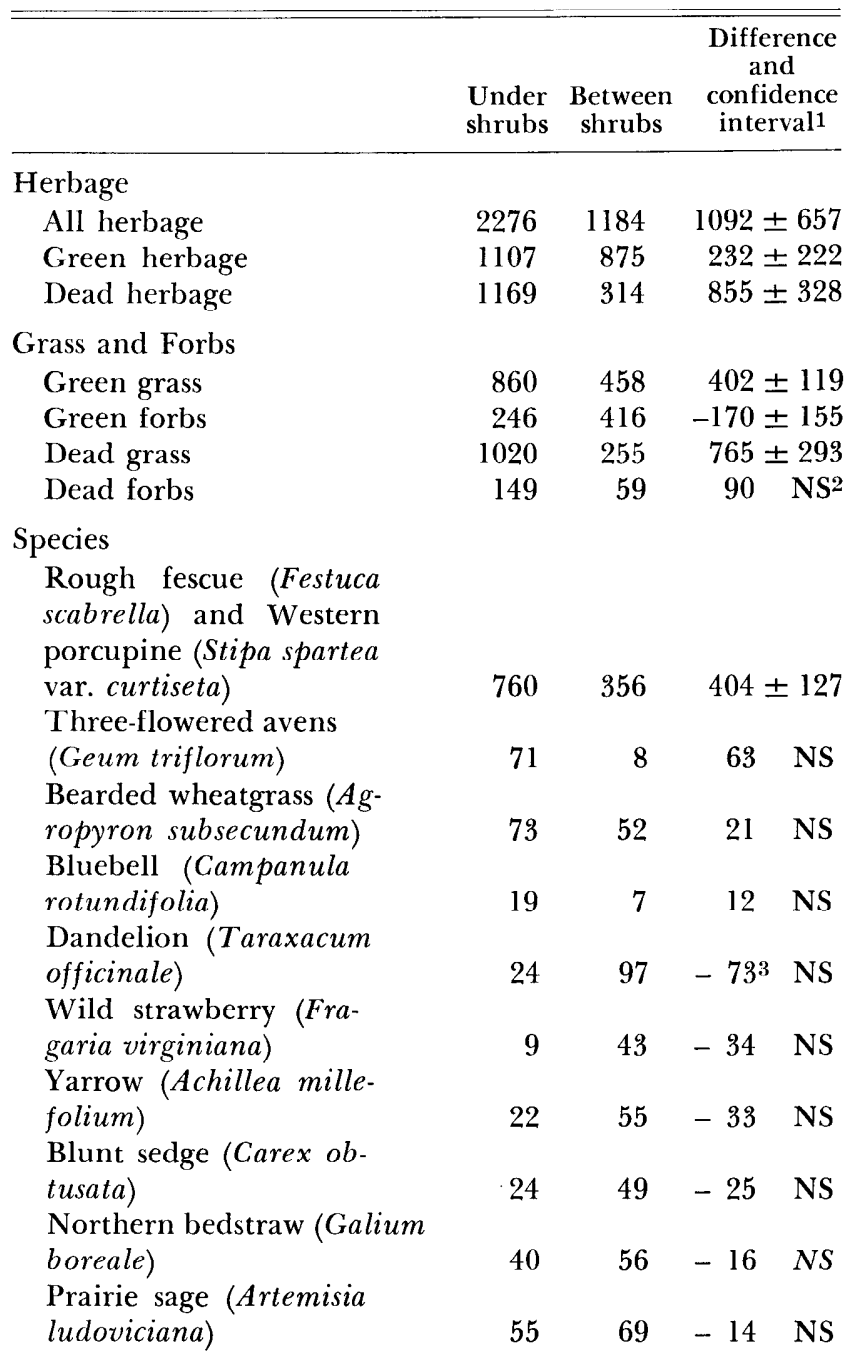

1 at $95 \%$ level, except for green forbs which is at $90 \%$ level of significance.

$2 \mathrm{NS}=$ no significant difference.

${ }^{3}$ negative sign $(-)$ indicates species with greater production between shrubs.

herbage. Green grass, most of which was rough fescue and western porcupine grass, continued to be double under shrubs what it was between shrubs (860 vs. $458 \mathrm{lb} / \mathrm{acre}$ ). There were fewer green forbs under shrubs (246 vs. $416 \mathrm{lb} /$ acre). There was four times as much dead grass under than between shrubs.

Cattle grazed less intensively upon the green herbage under shrubs than on that between shrubs (34 vs. $46 \%$ ) (Table 3, Fig. 2) but actual weight grazed was about equal ( 379 vs. $399 \mathrm{lb} /$ acre). The amount of dead material eaten was very different under shrubs versus between them (311 vs. $89 \mathrm{lb} /$ acre) but the percentage used was the same. On the average, more forage was eaten under the shrubs (699 vs. $488 \mathrm{lb} / \mathrm{acre}$ ) but more intensive 
Table 3. Weight (lb/acre) of forage eaten and level of use (\%) sustained under shrubs versus in opening between shrubs.

\begin{tabular}{|c|c|c|c|c|}
\hline & \multicolumn{2}{|c|}{ Amount grazed } & \multicolumn{2}{|c|}{ Percentage use } \\
\hline & $\begin{array}{l}\text { Under } \\
\text { shrubs }\end{array}$ & $\begin{array}{c}\text { Between } \\
\text { shrubs }\end{array}$ & $\begin{array}{l}\text { Under } \\
\text { shrubs }\end{array}$ & $\begin{array}{r}\text { Betweer } \\
\text { shrubs }\end{array}$ \\
\hline \multicolumn{5}{|l|}{ Herbage } \\
\hline All herbage & 690 & 488 & 30 & 41 \\
\hline Green herbage & 379 & 399 & 34 & 46 \\
\hline Dead herbage & 311 & 89 & 27 & 28 \\
\hline \multicolumn{5}{|l|}{ Grass and forbs } \\
\hline Green grass & 310 & 176 & 34 & 42 \\
\hline Green forbs & 69 & 223 & 28 & 54 \\
\hline Dead grass & 377 & 107 & 37 & 38 \\
\hline \multicolumn{5}{|l|}{ Species } \\
\hline $\begin{array}{l}\text { Rough fescue and West- } \\
\text { ern porcupine grass }\end{array}$ & 301 & 170 & 40 & 48 \\
\hline Bluebell & 18 & 7 & 94 & 97 \\
\hline Three-flowered avens & 70 & 5 & 98 & 66 \\
\hline Prairie sage & 17 & 17 & 31 & 25 \\
\hline Bearded wheatgrass & 19 & 12 & 25 & 23 \\
\hline Northern bedstraw & $-8^{1}$ & 46 & $-20^{1}$ & 82 \\
\hline Yarrow & -1 & 37 & -5 & 71 \\
\hline Wild strawberry & -2 & 16 & -22 & 37 \\
\hline Dandelion & -17 & 32 & -71 & 33 \\
\hline Blunt sedge & -30 & 14 & -125 & 29 \\
\hline
\end{tabular}

${ }^{1}$ negative sign (-) indicates a greater weight in grazed plots than in ungrazed ones.

use was sustained in openings between shrubs (41 vs. $30 \%$ ). Similarly, greater use occurred on green grass between the shrubs (42 vs. $34 \%$ ) but the amount eaten was less than under the shrubs (176 vs. $310 \mathrm{lb} /$ acre). More green forbs were eaten between the shrubs (223 vs. $69 \mathrm{lb} /$ acre) and the percentage use was higher ( 54 vs. $28 \%$ ).

Northern bedstraw, yarrow, wild strawberry, blunt sedge, and dandelion produced more under shrubs in grazed areas than in ungrazed areas. These species were apparently able to grow more rapidly after grazing than the dominate grasses. In the exclosures, the ungrazed grass probably prevented comparable growth. More intensive grazing has probably occurred for years between shrubs. It has reduced grass yield and allowed all five species mentioned above to increase (Table 2).

The breeding herd of cattle requires a relatively constant amount of forage each spring but the forage supply varies from year to year. The intensity of forage use is inversely related to forage supply. In 1967, percentage use of green herbage was $34 \%$ under shrubs and $46 \%$ between shrubs (Table 3). These differences were not large and did not seem to account for the major differences in species composition and production under shrubs versus between them. The small differences in percentage use in 1967 were probably due to

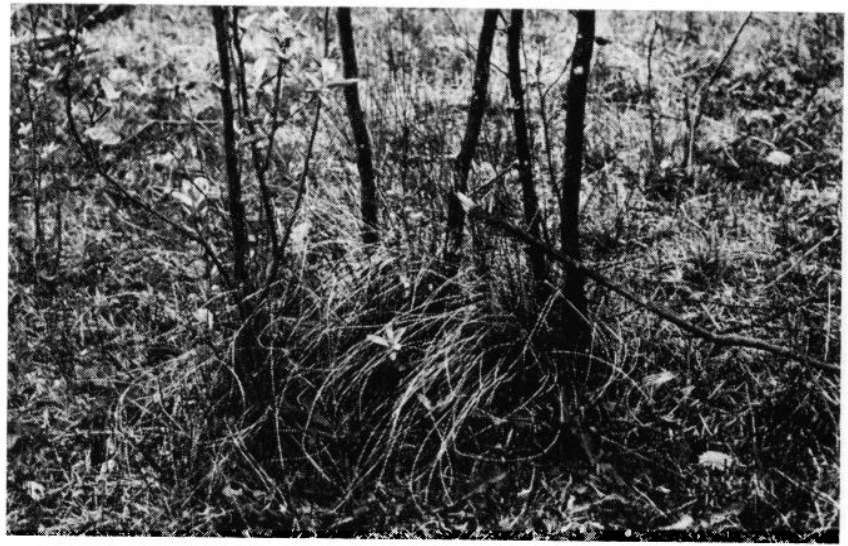

FIG. 2. A patch of lightly grazed grassland protected by silverberry stems.

high forage production, a result of heavy precipitation in August, 1966 and the spring of 1967. Greater differences in the percentage of forage used under shrubs versus between them could probably be expected in average or dry years.

Amounts of herbage remaining at the end of two grazing seasons (carry over) are compared in Table 4 to evaluate the effect of precipitation and associated factors on yield. Herbage left after the 1966 grazing season was estimated from the weathered material harvested in ungrazed plots. 1966 had below normal precipitation ( 1.5 inches) while 1967 had above normal precipitation (4 inches) in May and June (Can. Dept. Transport, Meteorol. Div. 1966, 1967). In 1967, there was a $25 \%$ increase in animal unit months of grazing. All categories had greater amounts left after the 1967 grazing season. There was $36 \%$ more forage under shrubs and $124 \%$ more between shrubs. Most of the increase can be attributed to the greater yield of forbs. Weathering during the winter of 1966-67 would reduce the weight of grass and forbs left

Table 4. Comparison of herbage (lb/acre $\left.{ }^{1}\right)$ left after 1967 grazing season with that left after 1966 grazing season.

\begin{tabular}{lccccc}
\hline & \multicolumn{2}{c}{ Weight } & & \multicolumn{2}{c}{ Percent change } \\
\cline { 2 - 3 } & $\begin{array}{l}\text { Under } \\
\text { shrubs }\end{array}$ & $\begin{array}{c}\text { Between } \\
\text { shrubs }\end{array}$ & & $\begin{array}{c}\text { Under } \\
\text { shrubs }\end{array}$ & $\begin{array}{r}\text { Between } \\
\text { shrubs }\end{array}$ \\
Herbage left-1967 & 1590 & 702 & & 36 & 124 \\
Herbage left-1966 & 1169 & 314 & & & \\
Grass left-1967 & 1190 & 439 & & & \\
Grass left-1966 & 1020 & 255 & & & \\
Forbs left-1967 & 400 & 263 & & & \\
Forbs left-1966 & 149 & 59 & & & \\
\hline
\end{tabular}

${ }^{1}$ all weight differences under shrubs versus between shrubs are significant at the $95 \%$ level with one exception, forbs left -1966 . 
after the 1966 grazing season and harvested in June, 1967. The $17 \%$ difference in weight of grass under shrubs (1020 lb/acre for 1966 vs. $1190 \mathrm{lb} /$ acre for 1967) probably closely reflects weathering loss. Although both grasses and forbs increased with increased precipitation, the forbs had the greater response. The variation in forage yield in response to precipitation and associated factors was greater on the poorer condition range between shrubs than on the excellent condition range under shrubs.

It has been demonstrated that fewer forbs occurred under the shrubs and many other forbs had a lower frequency and yield (Table 1 and 2). Rough fescue and western porcupine grass yielded twice as much under the shrubs and their leaves were twice as long. These grass species were the dominants of the herbaceous layer and produced 60 $70 \%$ of the total annual yield. Grassland patches under the shrubs appeared to be equivalent to the relict rough fescue grasslands studied by Moss and Campbell (1947). The differences in species composition and dominance under shrubs versus between them are probably caused by a difference in grazing intensity. The mechanical barrier effect of the shrub is considered the major factor influencing grazing intensity. The nitrogen-fixing property of silverberry does not seem to be an influencing factor since Frischknecht (1963) found that rubber rabbitbrush, a shrub that does not fix nitrogen, had a similar effect on cattle grazing crested wheatgrass.

Moss and Campbell (1947) indicated that silverberry rapidly expanded on overgrazed range in the parkland region by means of long rhizomes. Therefore, silverberry is considered an increaser. It seems unusual that one of the effects of this increaser is to help restore a part of the range to near-climax condition. The only part of the range in excellent condition was that directly beneath the shrubs.

The patches of excellent condition range under shrubs made up about $10 \%$ of the area. The remainder was in fair to good range condition. Actual influence of the shrubs on herbaceous vegetation was probably more widespread, since in this area rough fescue is rhizomatous. Grass plants protected by the shrubs probably extended into openings between shrubs. Plants growing partly under a shrub and partly in the open were probably more vigorous than those plants not so protected.
Silverberry at 1000 stems/acre had a beneficial effect on forage production under spring grazing in the rough fescue grassland studied. The results probably apply as well to extensive areas of the thin-black soils in central Alberta. It is not known, however, how dense the silverberry must be before the shrub creates a distribution problem for grazing cattle. Grazing is probably effectively prevented in very dense stands of silverberry that occur on fertile soils of the black soil zone.

\section{Literature Cited}

Blaisdell, J. P. 1949. Competition between sagebrush seedlings and reseeded grasses. Ecology 30:512-519.

Canada Department of Transport, Meteorological Division. 1966, 1967. Monthly Record of Meteorological Observation. Ottawa.

Corns, Wm. G., and R. J. SchraA. 1965. Mechanical and chemical control of silverberry (Elaeagnus commutata Bernh.) on native grassland. J. Range Manage. 18:15-19. Coupland, R. T., and T. C. Brayshaw. 1953. The fescue grassland in Saskatchewan. Ecology 34:386-405.

DAubenmire, R. 1968. Plant communities; a textbook of synecology. New York, Harper and Row. $300 \mathrm{p}$.

FrischkNeGHT, N. C. 1963. Contrasting effects of big sagebrush and rubber rabbitbrush on production of crested wheatgrass. J. Range Manage. 16:70-74.

Ivans, G. W. 1960. Species of Acacia as weeds. In Harper, J. L. ed. The Biology of Weeds. 167-175.

Johnston, A., AND S. Smoliak. 1968. Reclaiming brushland in southwestern Alberta. J. Range Manage. 21: 404-406.

Little, E. C. S. 1961. The ecology of some New Zealand woody weeds. In Harper, J. L. ed. The Biology of Weeds. 176-183. Blackwell, London.

MCIver, R. N. 1963. Brush control on native pastures. In Research report. National Weed Committee, Western Section. 194-195. Ottawa.

Moore, A. W. 1964. Non-leguminous nitrogen fixing plants in Alberta. Can. J. Bot. 42:952-955.

Moss, E. H. 1959. Flora of Alberta. Toronto, Univ. Toronto Press. 546 p.

Moss, E. H., and J. A. Campbell. 1947. The fescue grassland of Alberta. Can. J. Research 25(c):209-227.

Robertson, J. H. 1947. Responses of range grasses to different intensities of competition with sagebrush (Artemisia tridentata Nutt.). Ecology 28:1-16.

ScotT, J. D. 1967. Advances in pasture work in South Africa. Herbage Abstr. 37(1):1-9.

Thomas, G. W. M., T. W. Box, ANd J. L. Schuster. 1968. The brush problem in Texas-a challenge to research. In Brush control research progress report. 3-5. Texas Tech. College Spccial Report No. 15.

\section{Specialists in Quality NATIVE GRASSES}

Wheatgrasses • Bluestems • Gramas • Switchgrasses $\bullet$ Lovegrasses $\bullet$ Buffalo $\bullet$ and Many Others

We grow, harvest, process these seeds

Your Inquiries

Appreciated

Native Grasses Harvested in ten States 